\title{
The Kuroshio
}





\section{The Kuroshio}

A Symposium on the Japan Current

Edited by John C. Marr

East-West Center Press

Honolulu 
This volume was published with the assistance of a grant from the United Nations Educational, Scientific, and Cultural Organization.

Copyright (C) 1970 by East-West Center Press University of Hawaii

All rights reserved

International Standard Book Number: 0-8248-0090-7

Library of Congress Catalog Card Number: 70-104044

Printed in the United States of America

First edition 